Volume 12, Nomor 2, November 2020, pp 233-255 Copyright (C) 2017

Jurnal Akuntansi, Program Studi Akuntansi, Fakultas Ekonomi, Universitas Kristen Maranatha. ISSN 2085-8698 | e-ISSN 2598-4977. http://journal.maranatha.edu

\title{
Pengaruh Karakteristik Direksi Terhadap Kinerja Perusahaan yang Terdaftar di Bursa Efek Indonesia
}

\author{
Audrey Winona Aprilia \\ Universitas Prasetiya Mulya \\ (BSD City Kavling Edutown I, Tangerang) \\ audrey.aprilia@student.pmsbe.ac.id \\ Renita Febriany \\ Universitas Prasetiya Mulya \\ (BSD City Kavling Edutown I, Tangerang) \\ renita.febriany@student.pmsbe.ac.id \\ Luciana Haryono \\ Universitas Prasetiya Mulya \\ (BSD City Kavling Edutown I, Tangerang) \\ luciana@pmbs.ac.id \\ Nany Chandra Marsetio \\ Universitas Prasetiya Mulya \\ (BSD City Kavling Edutown I, Tangerang) \\ nany.marsetio@pmbs.ac.id
}

\begin{abstract}
Directors are human resources who play an important role in maintaining the long-term sustainability of the company's business. Thus, this study aims to determine board size, CEO tenure, and foreign director on company performance in the non-financial industry on the Indonesia Stock Exchange in 2013-2018 with multiple linear regression analysis using 1,764 sample data from 294 companies. Contributions in this study using resource dependency theory, stewardship theory and foreign directors variables as indicators of independence. The results of the study board size have a significant positive effect on company performance, with an optimal number of 4-9 people because it can provide diverse perspectives and ideas in decision making. CEO tenure does not affect ROA and ROE because the president director tends to reject and avoid risks and company's performance is influenced by all directors, not just the president director. Foreign directors have a significant positive effect on ROA with an optimal percentage of $26-50 \%$ because they provide different perspectives on decision making, but does not affect ROE with $51-75 \%$ of the optimal amount because does not have large influence to influence decisions in improving company performance.
\end{abstract}

Keywords: Director's Characteristics, Firm Performance, Resource Dependency Theory, Stewardship Theory. 


\begin{abstract}
Abstrak
Direksi merupakan sumber daya manusia yang berperan penting dalam menjaga keberlangsungan usaha perusahaan dalam jangka panjang. Sehingga, penelitian ini bertujuan untuk mengetahui jumlah direksi, masa jabatan presiden direktur, dan direksi kewarganegaraan asing terhadap kinerja perusahaan pada industri non-keuangan di Bursa Efek Indonesia (BEI) pada tahun 2013-2018 dengan analisis regresi linear berganda menggunakan 1.764 data sampel dari 294 perusahaan. Kontribusi pada penelitian ini adalah menggunakan resource dependency theory, stewardship theory serta variabel direksi asing sebagai indikator independensi. Hasil penelitian jumlah direksi berpengaruh positif signifikan terhadap kinerja perusahaan, dengan jumlah optimal sebanyak 4-9 orang karena dapat memberikan sudut pandang dan ide yang beragam dalam pengambilan keputusan. Masa jabatan presiden direktur tidak mempengaruhi terhadap ROA dan ROE karena presiden direktur cenderung menolak dan menghindari risiko maupun perselisihan dan kinerja perusahaan dipengaruhi oleh seluruh direksi bukan hanya presiden direktur saja. Direksi asing berpengaruh positif signifikan terhadap ROA dengan persentase yang optimal adalah sebesar $26-50 \%$ karena memberikan perspektif yang berbeda dalam pengambilan keputusan, namun tidak mempengaruhi ROE dengan 51-75\% jumlah optimal karena tidak memiliki pengaruh yang besar untuk mempengaruhi keputusan dalam meningkatkan kinerja perusahaan.
\end{abstract}

\title{
Kata Kunci: Karakteristik Direksi, Kinerja Perusahaan, Resource Dependency Theory, Stewardship Theory
}

\section{Pendahuluan}

Sistem tata kelola merupakan sebuah peraturan yang mengatur mengenai manajemen internal perusahaan dengan pihak eksternal perusahaan seperti pemegang saham, pihak kreditur dan pemerintah yang mengatur hak dan kewajiban seluruh pemangku kepentingan perusahaan untuk mendapatkan informasi yang transparan mengenai perusahaan (Cadbury Committee of United Kingdom, 1992). Pada tahun 2004, pemerintah Indonesia membentuk Komite Nasional Kebijakan Governance (KNKG) untuk mendukung terciptanya pelaksanaan tata kelola yang baik dan menghasilkan pedoman tata kelola perusahaan yang baik pada tahun 2006 yang berisikan arahan untuk membangun, mengaktualkan, dan penerapan tata kelola yang baik. Pedoman ini bertujuan untuk menciptakan kompetisi perusahaan yang sehat dan kooperatif, sehingga dapat mendukung peningkatan ekonomi dan menjaga ekonomi tetap stabil (KNKG, 2006) dengan menerapkan prinsip transparansi, pertanggungjawaban (responsibilitas), independensi, dan kewajaran dan kesetaraan.

Direksi dalam menjalankan tugasnya akan dipimpin oleh presiden direktur yang bertugas untuk mengatur dan menyelaraskan kegiatan direksi (KNKG, 2006). Hal ini didukung oleh resource dependence theory yang menyatakan di dalam sebuah perusahaan terdapat individu yang diharapkan memiliki tujuan untuk mendukung dan berfokus pada pemecahan masalah yang akan ditunjuk sebagai direksi (Pfeffer dan Salancik, 1978) dan teori stewardship yang menyatakan direksi tidak akan bertindak berlawanan dengan tujuan pemilik (Donaldson \& Davis, 1994) dan menganggap tindakan manajer dapat dipercaya (Donaldson \& Preston, 1995). 
Meskipun Indonesia telah memiliki peraturan mengenai sistem tata kelola, namun nyatanya berdasarkan daftar 50 Emiten Terbaik dalam praktik tata kelola di ASEAN dalam ajang penganugerahan ASEAN Corporate Governance Awards 2015, hanya PT Bank Danamon Tbk dan PT Bank CIMB Niaga Tbk yang termasuk di dalamnya (cnnindonesia.com, 2017). Hal ini diperkuat dengan penilaian dari The Asian Corporate Governance Association (ACGA) (cnbcindonesia.com, 2019) pada tahun 2018, Indonesia menempati posisi terendah dalam penerapan sistem tata kelola pada perusahaan swasta maupun perusahaan milik pemerintah. Penerapan sistem tata kelola yang lemah juga dapat dibuktikan dari adanya beberapa kasus yang muncul beberapa tahun terakhir, seperti pada kasus PT Tiga Pilar Sejahtera Food Tbk (AISA) pada tahun 2018 karena gagal membayar utang obligasi, PT Garuda Indonesia Tbk (GIAA) pada tahun 2018 terkait kasus penyajian laporan keuangan yang salah, direksi PT Hanson International Tbk (MYRX) pada tahun 2019 atas tindakan pelanggaran peraturan perundangundangan pasar modal terkait Kavling Siap Bangun (Kasiba), dan masih banyak lagi.

Berdasarkan kasus yang telah disebutkan, terbukti bahwa direksi, sebagai pengelola perusahaan, memiliki pengaruh terhadap kinerja perusahaan (Hossain, Cahan \& Adams, 2000). Kinerja perusahaan merupakan indikator keuangan untuk mengukur hasil kebijakan dan operasi perusahaan yang sedang atau telah dicapai dalam hal keuangan atau moneter, sehingga dapat mengukur kesehatan keuangan perusahaan dalam periode tertentu (Ravinder \& Anitha, 2013). Kinerja keuangan salah satunya dapat diukur menggunakan analisis profitabilitas, yaitu return on assets (ROA) dan return on equity (ROE). Efektivitas kinerja perusahaan dapat diwujudkan dengan peran direksi yang melaksanakan perannya secara efektif untuk mengelola perusahaan, sehingga direksi perlu dibentuk dengan menggabungkan kompetensi (KNKG, 2006) dan keahlian untuk menciptakan struktur tata kelola yang lebih unggul (Pearce \& Zahra, 1989).

Karakteristik direksi dalam sebuah perusahaan diperlukan untuk menjalankan tugas direksi secara efektif sesuai dengan prinsip dasar direksi pada Pedoman Umum Good Corporate Governance (KNKG, 2006). Prinsip direksi yang diatur adalah mengenai komposisi direksi, bersikap profesional dengan integritas, pengalaman, kapabilitas serta disesuaikan dengan kompleksitas perusahaan agar dapat menghasilkan keputusan yang efektif, akurat, cepat, dan bertindak independen. Dengan adanya direksi berkewarganegaraan asing dalam direksi, kepentingan investor dapat terlindungi karena investor percaya bahwa perusahaan dikelola secara profesional untuk seluruh pemangku kepentingan (Oxelheim \& Randoy, 2003). Kinerja keuangan perusahaan juga dapat dipengaruhi dari masa jabatan direksi. Semakin lama direksi menjabat sebagai direksi suatu perusahaan, maka memiliki kompetensi dan komitmen yang lebih besar (Vafeas, 2003) dan akan menurunkan kemungkinan terjadinya kecurangan pada pembuatan dan pelaporan laporan keuangan (Beasley, 1996).

Berdasarkan isu tata kelola di Indonesia dan penelitian terdahulu yang belum konsisten, maka penelitian ini akan membahas mengenai "Pengaruh Karakteristik Direksi terhadap Kinerja Perusahaan yang Terdaftar di Bursa Efek Indonesia" pada sektor non- keuangan pada tahun 2013-2018. Periode penelitian ini merupakan replikasi dari penelitian Salehi, Tahervafaei dan Tarighi (2017) yang meneliti mengenai pengaruh karakteristik direksi terhadap profitabilitas di perusahaan Iran. Penelitian ini dilakukan dengan tujuan untuk melihat kebaruan dalam pengaruh karakteristik direksi terhadap kinerja keuangan pada perusahaan yang ada di Indonesia. Karakteristik direksi diukur berdasarkan jumlah direksi, masa jabatan 
presiden direktur, dan direksi dengan kewarganegaraan asing terhadap kinerja perusahaan dengan basis akuntansi, yaitu return on assets (ROA) dan return on equity (ROE).

Penelitian ini akan berbeda dengan penelitian terdahulu yang menguji pengaruh karakteristik direksi terhadap kinerja perusahaan. Peneliti-peneliti terdahulu menggunakan teori keagenan yang menjelaskan adanya konflik perbedaan kepentingan antara pemilik dan pengelola modal, sedangkan dalam penelitian ini ingin menunjukkan bahwa direksi sebagai pengelola perusahaan memiliki pengaruh positif terhadap kinerja perusahaan. Para pemilik modal mempercayai dan menunjuk direksi melalui Rapat Umum Pemegang Saham (RUPS) yang dipercaya untuk untuk mendukung organisasi dan berfokus pada pemecahan masalah organisasi tersebut (Pfeffer \& Salancik, 1978), serta tindakannya termotivasi untuk kepentingan perusahaan (Donaldson \& Davis, 1989). Sehingga, stewardship theory yang dikaitkan dengan teori loyalitas dan resource dependence theory akan digunakan dalam penelitian ini. Selain itu, untuk mengukur independensi direksi dalam mengelola perusahaan, penelitian ini juga meneliti direksi dengan kewarganegaraan asing yang diharapkan dapat meningkatkan kinerja. Hal ini dikarenakan direksi merupakan aset bagi perusahaan yang berkontribusi dalam menjaga keberlangsungan usaha perusahaan (Hillman, Withers \& Collins, 2009), sehingga independensi direksi dapat mempengaruhi kinerja perusahan.

\section{Rumusan Masalah}

Berdasarkan latar belakang penelitian, maka pertanyaan penelitian ini adalah sebagai berikut :

1. Apakah jumlah direksi berpengaruh positif terhadap kinerja perusahaan?

2. Apakah masa jabatan presiden direktur berpengaruh positif terhadap kinerja perusahaan?
3. Apakah direksi dengan kewarganegaraan asing berpengaruh positif terhadap kinerja perusahaan?

\section{Tujuan Penelitian}

Penelitian ini memiliki tujuan untuk:

1. Menganalisis pengaruh jumlah direksi terhadap kinerja perusahaan.

2. Menganalisis pengaruh masa jabatan presiden direktur terhadap kinerja perusahaan.

3. Menganalisis pengaruh direksi dengan kewarganegaraan asing terhadap kinerja perusahaan.

\section{Kerangka Teoritis dan Hipotesis}

\section{Stewardship Theory}

Stewardship theory menjelaskan bahwa tindakan manajer yang tidak dilandaskan oleh kepentingan pribadi, melainkan untuk kepentingan perusahaan (Donaldson \& Davis, 1989). Tindakan manajer dapat dipercaya (Donaldson \& Preston, 1995) karena pengelolaan perusahaan difokuskan pada harmonisasi pemilik modal dan pengelola modal untuk mencapai tujuan bersama (Anton, 2010) sehingga tidak ada konflik kepentingan karena memiliki tujuan yang searah (Jhunjhunwala \& Mishra, 2012). Hal ini dikarenakan perilaku manajerial yang dilakukan oleh pengelola modal tidak didasari oleh motif keuangan, tetapi berdasarkan kebutuhan akan prestasi dan pengakuan, kepuasan atas kinerja yang sukses, penghormatan otoritas dan etika kerja (Jefri, 2018). Pada dasarnya, manajer eksekutif ingin menjadi pelayan yang baik dan dianggap sebagai aset perusahaan, sehingga Ia tidak mungkin berkhianat terhadap perusahaan (Donaldson \& Davis, 1991). Teori stewardship sebagai pelayan yang setia terhadap perusahaan dapat digambarkan melalui loyalitas, komitmen, dan tanggung jawab atas kewajibannya (Cook \& Burress, 2013). Elegido (2013) mendefinisikan loyalitas sebagai komitmen untuk memajukan kepentingan bersama, meskipun dapat mengorbankan aspek 
kepentingan diri sendiri. Selain itu, karyawan yang loyal kepada perusahaan akan melakukan yang terbaik dalam melayani, memberikan pengaruh langsung kepada perusahaan, dan memberikan kinerja yang signifikan (Tomic, Tesic, Kuzmanovic \& Tomic, 2018).

\section{Resource Dependence Theory}

Resource Dependence Theory (RDT) diperkenalkan oleh Pfeffer \& Salancik (1978) yang menyatakan strategi, struktur, dan keberlangsungan hidup perusahaan sangat bergantung pada sumber daya untuk menghubungkan dengan lingkungan eksternal. Sumber daya tersebut ditunjuk sebagai direksi yang bertugas untuk melakukan kegiatan operasional, mendukung organisasi, dan berfokus pada pemecahan masalah (Aldrich \& Pfeffer, 1976; Pfeffer \& Salancik, 1978). Menurut RDT, direksi merupakan aset perusahaan yang berkontribusi dalam menjaga keberlangsungan usaha perusahaan (Hillman et al., 2009), maka direksi akan terlibat dalam tugas pemantauan dan memberikan saran dalam membuat keputusan (Hillman \& Dalziel, 2003). Keberagaman direksi, seperti jumlah direksi dan direksi kewarganegaraan asing, akan memberikan pengaruh yang baik dalam mengidentifikasi, evaluasi strategi dengan alternatif yang lebih komprehensif, dan menciptakan hubungan dengan lingkungan eksternal karena keberagaman keterampilan yang dimiliki oleh direksi (Singh, 2007; Ujunwa, 2012).

\section{Tata Kelola Perusahaan}

Gillan dan Starks (1998) mendefinisikan tata kelola perusahaan sebagai sistem hukum, aturan, dan faktor-faktor yang mengendalikan operasi di suatu perusahaan. Sistem tata kelola Indonesia diatur dalam Keputusan Menteri Negara BUMN No. Kep-117/M-MBU/2002 dan pada tahun 2004, Indonesia bergabung dengan Organization for Economic Cooperation \& Development (OECD) agar menjadi tolak ukur pemerintah untuk meningkatkan perundang-undangan sistem tata kelola. Pada dasarnya, tata kelola memiliki 5 prinsip yang harus diterapkan oleh perusahaan yaitu transparansi, kemandirian, akuntabilitas, pertanggungjawaban, dan kewajaran dan kesetaraan. Manfaat pelaksanaan sistem tata kelola pada perusahaan untuk mewujudkan pelaksanaan usaha yang sehat agar dapat menunjang pertumbuhan ekonomi berkelanjutan dan meningkatkan kesempatan kerja, serta melaksanakan etika bisnis secara konsisten, termasuk untuk mencegah dan menghilangkan tindakan Korupsi, Kolusi, dan Nepotisme (KKN) (KNKG, 2006).

\section{Karakteristik Direksi}

Struktur dan mekanisme organisasi yang jelas dan baik menjadikan sebuah organisasi efektif dalam mencapai tujuan yang mengarah pada keberhasilan kinerja dan mendorong kelangsungan hidup organisasi (KNKG, 2006). Oleh karena itu, direksi sebagai penanggung jawab pengelolaan perusahaan akan dipengaruhi oleh karakteristik direksi yang dapat diukur dengan pengukuran jumlah direksi, masa jabatan presiden direktur dan direksi dengan kewarganegaraan asing.

Jumlah direksi merupakan banyaknya direksi yang secara aktif berpartisipasi sebagai anggota direksi dalam suatu perusahaan (Muttakin, Khan \& Subramaniam, 2012). Dengan tugas direksi yang banyak, maka tidak mungkin jika perusahaan hanya memiliki seorang direksi. Jumlah direksi diatur dalam UndangUndang Republik Indonesia No. 19 tahun 2003 tentang Badan Usaha Milik Negara pasal 16 ayat 5, UU PT No 40/2007 pasal 98 ayat 2, dan Peraturan Otoritas Jasa Keuangan POJK no. 33/POJK.04/2014 tentang Direksi dan Komisaris Emiten atau Perusahaan Publik. Ketiga peraturan tersebut mengatur jumlah direksi dalam perusahaan minimal terdiri 2 orang, yang salah satunya diangkat sebagai presiden direktur. 
Masa jabatan presiden direktur adalah lamanya seorang presiden direktur menjabat dalam suatu perusahaan (Trivedi, 2005). Di Indonesia, seorang direksi akan diangkat melalui RUPS untuk menjabat dalam jangka waktu tertentu dan dapat diangkat kembali (UU PT No. 40/2007 pasal 94 ayat 3) yang berlaku bagi perseroan terbatas non-BUMN dan tidak dijelaskan mengenai jangka waktu maksimal. Sedangkan, untuk BUMN yang diatur dalam UU RI No. 19 tahun 2003 tentang Badan Usaha Milik Negara pasal 16 ayat 4 dan perusahaan publik yang diatur dalam POJK no. 33/POJK.04/2014 tentang Direksi dan Komisaris Emiten atau Perusahaan Publik memiliki kesamaan peraturan. Kedua peraturan tersebut mengatur masa jabatan direksi selama 5 tahun dan dapat diangkat kembali untuk 1 kali masa jabatan.

Direksi dengan kewarganegaraan asing adalah direksi yang bukan Warga Negara Indonesia (WNI) namun mewakili negara tertentu diluar Indonesia dan telah menjabat sebagai direksi pada suatu perusahaan minimal selama 1 tahun (Trivedi, 2015). Aturan mengenai pekerja asing yang ada di Indonesia diatur melalui Peraturan Presiden (Perpres) Nomor 20 Tahun 2018 tentang Penggunaan Tenaga Kerja Asing (TKA) yang mengatur bahwa setiap tenaga kerja asing yang dipekerjakan di suatu lembaga, termasuk perusahaan harus memiliki Visa Tinggal Terbatas (VITAS) memuat persetujuan mengenai perjalanan ke wilayah Indonesia, serta memiliki Izin Tinggal Terbatas (ITAS) merupakan izin kepada orang asing untuk tinggal dan berada di wilayah Indonesia dalam periode bekerja. Perusahaan sebagai pemberi kerja bagi TKA berkewajiban untuk mendaftarkan jaminan sosial ketenagakerjaan atau sosial bagi TKA yang bekerja lebih dari 6 bulan, melakukan pelatihan sesuai jabatan, dan memberikan fasilitas pelatihan dan pendidikan Bahasa Indonesia.

\section{Kinerja Perusahaan}

Kinerja keuangan digunakan untuk mengukur keberhasilan atau efektivitas suatu organisasi dan dijadikan sebagai indikasi organisasi yang efektif untuk mencapai tujuannya dengan sukses (Cherrington, 1989). Pengukuran kinerja perusahaan dapat dilakukan dengan basis akuntansi (Palaniappan, 2017) banyak digunakan ketika menyelidiki hubungan antara tata kelola dan kinerja perusahaan (Hutchinson \& Gul, 2004) dengan menggunakan rasio profitabilitas yaitu return on asset (ROA) dan return on equity (ROE) (Mishra \& Kapil, 2017). ROA adalah indikator yang digunakan untuk mengukur efisiensi manajemen perusahaan dalam mengelola aset yang dimiliki untuk memperoleh pendapatan (Bachiller, Giorgino \& Paternostro, 2014). Sedangkan indikator yang dipakai untuk mengukur efisiensi manajemen perusahaan dalam menggunakan ekuitasnya untuk memperoleh pendapatan dan nilai bagi para pemilik saham adalah ROE, yang dapat digunakan sebagai indikator penting untuk keputusan berinvestasi dalam sebuah perusahaan (Bachiller et al., 2014).

\section{Pengembangan Hipotesis \\ Pengaruh Jumlah Direksi Terhadap Kinerja Perusahaan}

Jumlah direksi adalah banyaknya direksi yang secara aktif berpartisipasi sebagai anggota direksi dalam suatu perusahaan (Muttakin et al., 2012) dan sering digunakan untuk meneliti sistem tata kelola. Direksi merupakan aset bagi perusahaan yang dapat berkontribusi dalam menjaga keberlangsungan usaha perusahaan (Hillman et al., 2009), sehingga jumlah direksi yang banyak dibutuhkan oleh perusahaan untuk meningkatkan koneksi antara perusahaan dan lingkungan eksternal (Pfeffer \& Salancik, 2003) yang mencakup latar belakang berbeda-beda (Pfeffer, 1972). Penelitian sistem tata kelola sering menggunakan jumlah direksi sebagai karakteristik direksi yang diteliti, namun 
hasil penelitian menunjukkan hasil yang beragam. Johl, Kaur, dan Cooper (2015) dan $\mathrm{Vu}$, Phan, dan Le (2018) menghasilkan hasil yang positif antara jumlah direksi dengan kinerja perusahaan. Hal ini dikarenakan jumlah direksi yang banyak dapat lebih efisien untuk melakukan monitoring dalam mencegah fraud (Johl et al., 2015) dan memiliki pengetahuan yang lebih luas untuk memberikan ide dan perspektif dalam pengambilan keputusan untuk meningkatkan kinerja perusahaan ( $\mathrm{Vu}$ et al., 2018). Sedangkan penelitian Merendino dan Melville (2018) dan Arora dan Sharma (2016), ketika jumlah direksi meningkat, direksi menjadi tidak efisien dalam melaksanakan tugasnya dan sulit bagi perusahaan untuk mengatur rapat direksi untuk mencapai kesepakatan mengenai masalah yang dibahas dalam rapat karena membutuhkan waktu yang lama untuk pengambilan keputusan dan akibatnya direksi menjadi tidak efisien dalam menangkap peluang bisnis (Judge dan Zeithaml, 1992).

Khanchel (2007) dan Yermack (1996) menyarankan untuk menambah jumlah direksi perusahaan karena ukuran perusahaan akan mempengaruhi kemampuan pemantauan direksi, karena kemampuan pemantauan lebih efektif pada jumlah direksi yang semakin banyak. Sehingga, hipotesis yang akan diuji adalah:

H1: Jumlah direksi berpengaruh positif terhadap kinerja perusahaan

\section{Pengaruh Masa Jabatan Presiden Direktur Terhadap Kinerja Perusahaan}

Masa jabatan presiden direktur merupakan faktor lain yang dapat mempengaruhi kinerja perusahaan (Naseem, Lin, Rehman, Ahmad \& Ali, 2009). Sebagai seorang direksi, diwajibkan untuk memberikan seluruh tenaga, pikiran, dan perhatian dalam rangka pemenuhan tugas, kewajiban, dan pencapaian dari perusahaan (UU No. 19/2003 pasal 19), serta bertugas untuk menjalankan kepentingan perusahaan sesuai dengan maksud dan tujuan perusahaan (UU
PT No. 40/2007 pasal 92 ayat 1). Oleh karena itu, tindakan direksi dapat dipercaya (Donaldson \& Preston, 1995) karena pengelolaan organisasi dalam mencapai tujuan akan difokuskan untuk menciptakan harmonisasi antara pemilik modal dan direksi sebagai pengelola modal (Anton, 2010).

Dalam menjalankan tugasnya, presiden direktur yang merupakan manajer eksekutif pada dasarnya ingin menjadi pelayan yang baik dari aset perusahaan dan jauh dari pengkhianatan perusahaan yang oportunistik (Donaldson \& Davis, 1991). Sehingga, dapat dikatakan bahwa presiden direktur merupakan karyawan yang loyal yang memberikan rasa cinta dan tanggung jawab yang ditunjukan dengan kesetiaan, pengabdian, dan kepercayaan terhadap perusahaan untuk memberikan pelayanan dan perilaku terbaik (Anwar, 2018). Dengan loyalitas yang tinggi, setiap menjalankan tugasnya selalu didasari dengan semangat dan tanggung jawab, serta terus berpikir untuk memajukan perusahaan (Gomes \& Sutanto, 2017).

Hartnell, Kinicki, Lambert, Fugate, dan Corner (2016) menyatakan bahwa semakin lama presiden direktur menjabat maka kepercayaan dan kekuatan yang dimiliki untuk membuat keputusan keuangan dan keputusan strategis dapat meningkatkan nilai perusahaan. Masa jabatan yang lebih lama akan meningkatkan pemahaman mengenai peran dan tanggung jawab, operasional perusahaan, rutinitas, strategi, dan pengambilan keputusan yang tepat untuk menghasilkan profitabilitas yang lebih tinggi dari aset perusahaan (Raymond, Paul, \& Kang, 2010). Sebaliknya, Naseem et al. (2019) menyatakan lamanya masa jabatan direksi akan menyebabkan kurangnya motivasi dan menurunnya kemampuan manajerial direksi yang berdampak pada penurunan kinerja keuangan perusahaan. Penelitian serupa yang dilakukan oleh Kartikaningdyah dan Putri (2017) menghasilkan tidak adanya pengaruh masa jabatan direksi terhadap 
kinerja keuangan perusahaan karena setiap direksi memiliki posisi yang setara dalam mencapai kinerja perusahaan, tidak didasari oleh lamanya jabatan.

Masa jabatan direksi yang lama akan memberikan pengetahuan yang lebih terkait perusahaan dan bertindak mewakili pemilik modal. Sebagai pengelola modal, direksi tidak memiliki konflik kepentingan dengan pemilik modal (Jhunjhunwala \& Mishra, 2012), sehingga presiden direktur akan menyusun strategi yang akan mewujudkan kinerja yang perusahaan yang unggul (Yasser \& Seamer, 2016). Sehingga, hipotesis yang akan diuji adalah:

H2: Masa jabatan presiden direktur berpengaruh positif terhadap kinerja perusahaan

\section{Pengaruh Direksi dengan Kewarganegaraan Asing Terhadap Kinerja Perusahaan}

Kehadiran direksi dengan kewarganegaraan asing diharapkan dapat memenuhi salah satu prinsip tata kelola, yaitu independensi. Setiap perusahaan wajib mengoperasikan perusahaan secara independen supaya seluruh tenaga kerja tidak ada dominasi dan intervensi dengan pihak lain (KNKG, 2006). Menurut Choi, Sul, dan Min (2012), direksi dengan kewarganegaraan asing memiliki tingkat independensi yang tinggi karena tidak memiliki hubungan afiliasi dengan pemegang saham mayoritas. Sehingga hadirnya direksi dengan kewarganegaraan asing dapat meningkatkan keunggulan kompetitif perusahaan dengan cara melindungi hak pemegang saham minoritas (Oxelheim \& Randoy, 2003).

Menurut RDT, keragaman direksi di suatu perusahaan, termasuk latar belakang dan budaya yang berbeda, akan membawa wawasan baru dalam menyelesaikan masalah dan meningkatkan kinerja perusahaan karena memiliki latar belakang, budaya, keterampilan, pengalaman, dan koneksi yang luas (Ujunwa, 2012). Teori ini sesuai dengan hasil penelitian Shukla (2018) yang menemukan hubungan positif karena adanya perspektif berbeda dalam memberikan alternatif keputusan karena memiliki kreativitas, inovasi dan pemahaman yang lebih baik mengenai permintaan pasar. Berbeda dengan penelitian yang dilakukan oleh Kaur \& Singh (2018), menemukan hubungan yang negatif antara direksi dengan kewarganegaraan asing dengan kinerja perusahaan karena akan menimbulkan kesenjangan sosial antar direksi akibat perbedaan demografi dan jumlahnya yang minoritas dapat menghambat pengambilan keputusan yang berdampak pada kinerja perusahaan.

Hasil penelitian terdahulu masih menghasilkan hubungan antara direksi dengan kewarganegaraan asing dengan kinerja keuangan yang berbeda-beda. Sehingga, hipotesis yang akan diuji adalah:

H3: Direksi dengan kewarganegaraan asing berpengaruh positif terhadap kinerja perusahaan

Kerangka penelitian pada penelitian ini adalah sebagai berikut:

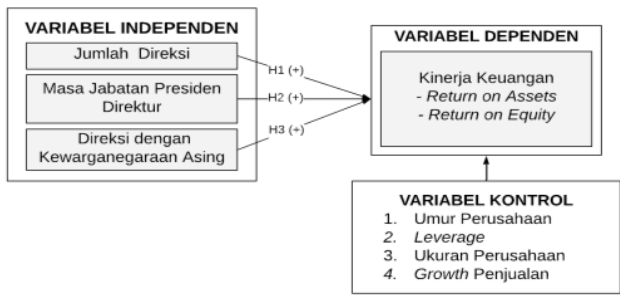

\section{Gambar 1 \\ Kerangka Penelitian Sumber: data diolah, 2020}




\section{Metode Penelitian}

\section{Jenis Penelitian dan Pemilihan Sampel}

Penelitian ini bersifat kuantitatif dengan menggunakan data sekunder yang diperoleh dari laporan tahunan dan laporan keuangan perusahaan yang telah dipublikasi pada idx.co.id ataupun website perusahaan, serta dilengkapi dengan data-data dari database Capital IQ. Tujuan penelitian ini adalah untuk mengetahui pengaruh karakteristik direksi terhadap kinerja keuangan pada perusahaan yang ada di BEI, sehingga populasi data yang digunakan dalam penelitian ini merupakan perusahaan yang terdaftar di BEI dari tahun 2013-2018. Pemilihan sampel penelitian digunakan metode purposive sampling dengan beberapa kriteria, yaitu perusahaan tidak mengalami delisting pada periode penelitian, perusahaan yang memiliki dan menerbitkan laporan tahunan dan laporan keuangan yang telah diaudit, perusahaan dengan data yang lengkap, dan industri keuangan dikeluarkan dari sampel karena memiliki peraturan yang berbeda, bentuk laporan keuangan berbeda, dan memiliki rasio lain yang dilihat oleh investor. Maka diperoleh sampel penelitian dari 294 perusahaan dengan 1.764 data.

\section{Pengukuran Variabel Variabel Independen}

Jumlah Direksi (BOARDSIZE) dapat diukur berdasarkan banyaknya direksi perusahaan yang bekerja pada tahun tersebut. Pengukuran ini sesuai dengan penelitian Palaniappan (2017) dan Mishra dan Kapil (2017).

\section{Masa Jabatan Presiden Direktur} (CEOTENURE) dapat diukur berdasarkan lamanya seorang presiden direktur menjabat dalam suatu perusahaan dengan pengukuran sebagai berikut :

- CEOTENURE = 1, jika masa jabatan presiden direktur dibawah 3 tahun.
- CEOTENURE = 2, jika masa jabatan presiden direktur selama 4-6 tahun.

- CEOTENURE = 3, jika masa jabatan presiden direktur selama 7-9 tahun.

- CEOTENURE = 4, jika masa jabatan presiden direktur selama 10-12 tahun.

- CEOTENURE = 5, jika masa jabatan presiden direktur selama 13-15 tahun.

- CEOTENURE = 6, jika masa jabatan presiden direktur diatas 15 tahun.

Pengukuran tersebut mengikuti penelitian Khan et al. (2019).

Direksi Dengan Kewarganegaraan Asing (Foreign) asing dapat diukur berdasarkan proporsi direksi dengan kewarganegaraan asing dengan pengukuran sebagai berikut:

FOREIGN $=\frac{\text { Direksi kewarganegaraan asing }}{\text { Jumlah direksi }}$

Pengukuran tersebut seperti penelitian Ling et al. (2015).

\section{Variabel Dependen}

Return on Asset (ROA) untuk mengukur kemampuan aset untuk menghasilkan laba di suatu perusahaan, dalam penelitian ini menggunakan pengukuran:

$$
R O A=\frac{\text { Laba Perusahaan }}{\left(\text { Total aset }_{t}+\text { Total aset }_{t-1}\right) / 2}
$$

Pengukuran ini mengacu pada penelitian Petria et al. (2015).

Return on Equity (ROE) untuk mengukur kemampuan ekuitas untuk menghasilkan laba di suatu perusahaan, dalam penelitian ini menggunakan pengukuran:

$$
R O E=\frac{\text { Laba Perusahaan }}{\text { (Total ekuitas } \left.s_{t}+\text { Total ekuitas }_{t-1}\right) / 2}
$$

Pengukuran ini mengacu pada penelitian Petria et al. (2015).

\section{Variabel Kontrol}

Umur Perusahaan (AGE) diukur menggunakan umur perusahaan sejak awal berdiri. Pengukuran yang digunakan adalah sebagai berikut :

$A G E=$ Umur perusahaan sejak idirikannya perusahaan 
Pengukuran tersebut mengikuti penelitian Palaniappan (2017) dan Mishra dan Kapil (2017).

Leverage (LEV) digunakan untuk mengukur aset yang diperoleh perusahaan dengan hutang dalam upaya meningkatkan nilai pemegang saham (investopedia.com, 2019). Rumus dari rasio leverage adalah sebagai berikut :

$$
L E V=\frac{\text { Total liabilitas }}{\text { Total aset }}
$$

Pengukuran ini telah digunakan dalam penelitian Palaniappan (2017).

Ukuran Perusahaan (SIZE) diukur menggunakan total aset perusahaan pada akhir tahun. Pengukuran yang digunakan adalah sebagai berikut:

$$
\text { SIZE }=\text { Total Aset }
$$

Pengukuran ini merujuk pada penelitian Mishra dan Kapil (2017) dan Naseem et al. (2019).

\section{Pertumbuhan Penjualan (GROWTH)} diukur menggunakan tingkat pertumbuhan penjualan bersih dibandingkan tahun sebelumnya. Pengukuran yang digunakan adalah sebagai berikut:

$$
\text { GROWTH }=\frac{\left(\text { Sales }_{t}-\text { Sales }_{t-1}\right)}{\text { Sales }_{t-1}}
$$

Pengukuran ini merujuk pada penelitian Palaniappan (2017) dan Mishra dan Kapil (2017).

\section{Model Penelitian}

Kinerja Perusahaan $_{i t}=\alpha+\beta_{1 \text { BOARD SIZE }}{ }_{i t}+$ $\beta_{2 \text { CEOTENURE }_{i t}}+\beta_{3 \text { FOREIGN }}+\beta_{4 \text { AGE }_{i t}}+$ $\beta_{5 L E V_{i t}}+\beta_{6 S I Z E_{i t}}+\beta_{7 G R O W T H_{i t}}+\varepsilon$

Keterangan:

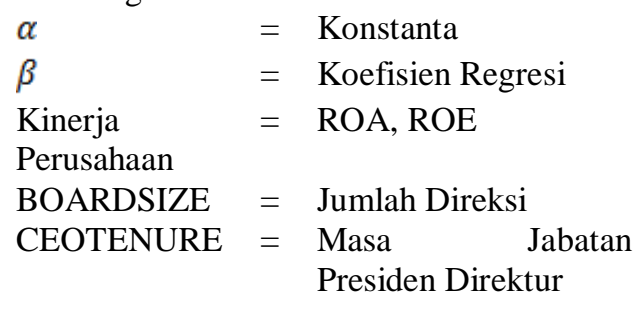

$\begin{array}{lll}\text { FOREIGN } & =\text { Direksi dengan } \\ & & \text { Kewarganegaraan } \\ & \text { Asing } \\ \text { AGE } & = & \text { Umur Perusahaan } \\ \text { LEV } & = & \text { Leverage } \\ \text { SIZE } & = & \text { Pkuran Perusahaan } \\ \text { GROWTH } & = & \text { Penjualan } \\ \mathrm{i} & = & \text { Perusahaan ke-i } \\ \mathrm{t} & = & \text { Tahun ke-t } \\ \varepsilon & = & \text { Error }\end{array}$

\section{Hasil Penelitian dan Pembahasan}

\section{Uji Asumsi Klasik}

Hasil dari uji asumsi klasik normalitas menunjukan hanya variabel CEOTENURE yang terdistribusi normal, sedangkan data variabel lainnya tidak terdistribusi normal meskipun telah dilakukan treatment $\ln$ (logaritma natural) pada variabel SIZE dan winsorizing pada seluruh variabel. Namun, karena penelitian ini menggunakan lebih dari 100 data, maka dapat dikatakan seluruh data sudah terdistribusi dengan normal, sesuai dengan asumsi Central Limit Theorem. Teori tersebut menyatakan bahwa jika jumlah observasi lebih dari 100 data, uji normalitas tidak perlu dilakukan (Gujarati \& Porter, 2009). Hasil pengujian variabel dependen ROA dan ROE menunjukan data telah terbebas dari multikolinearitas, namun tidak terbebas dari masalah heteroskedastisitas. Sedangkan pada uji autokolinearitas, variabel ROA tidak terbebas dan ROE bebas. Namun setelah dilakukan treatment menggunakan estimasi Driscoll Kraay, untuk model regresi ROA dan ROE sudah terbebas dari masalah heteroskedastisitas dan autokorelasi (Hoechle, 2007).

\section{Uji Ketepatan Model}

Uji ketepatan model dilakukan dengan 3 pengujian, yaitu Uji Chow, Uji Hausman, dan Uji Lagrange Multiplier (LM) yang dilakukan secara terpisah antara ROA dan 
ROE. Hasil uji menunjukkan model Fixed Effect merupakan model yang tepat untuk kedua variabel dependen berdasarkan hasil pengujian uji Chow dan uji Hausman. Namun, dalam penelitian ini akan menggunakan Pooled $O L S$ untuk ROA dan ROE sesuai dengan penelitian terdahulu yang serupa yang menggunakan model regresi Pooled OLS, seperti yang telah dilakukan oleh Mishra dan Kapil (2017), Johl et al. (2015), Ferraz, Lopes \& Kopliku (2018), dan Temprano dan Gaite (2019). Menurut Mishra dan Kapil (2017), penggunaan model Pooled OLS dianggap lebih sesuai karena lingkungan perusahaan lebih dipengaruhi dengan kondisi ekonomi politik, sebagai faktor sosial, dibandingkan dengan faktor dari dalam perusahaan tersebut. Oleh karena itu, intersep antar perusahaan tidaklah sama seperti pada model Fixed Effect.

\section{Statistik Deskriptif}

\section{Tabel 2}

Hasil Statistik Deskriptif

\begin{tabular}{|lrccc|}
\hline Variabel & Min & Max & \multicolumn{3}{c|}{ Mean Std.Dev } \\
\hline ROA & $-1,78$ & 1,1 & 0,036 & 0,131 \\
\hline ROE & $-40,47$ & 16,4 & 0,043 & 1,282 \\
\hline BOARDSIZE & 2 & 16 & 4,944 & 1,924 \\
\hline CEOTENURE & 1 & 6 & 2,474 & 1,785 \\
\hline FOREIGN & 0 & 1 & 0,128 & 0,213 \\
\hline AGE & 5 & 162 & 35,44 & 19,09 \\
\hline LEV & 0 & 1.951 & 54,35 & 80,103 \\
\hline SIZE & 46.761 & $3,45 \mathrm{e}^{8}$ & $1,085 \mathrm{e}^{7}$ & $2,36 \mathrm{e}^{7}$ \\
\hline GROWTH & $-0,98$ & 616,88 & 0,542 & 14,83 \\
\hline
\end{tabular}

Hasil pengujian statistik deskriptif dari 294 perusahaan dengan 1.764 data pada setiap variabel memperlihatkan nilai rata-rata dari variabel ROA dan ROE adalah sebesar 0,0356 dan 0,0427 . Hasil rata-rata nilai BOARDSIZE adalah sebesar 4,944 dengan nilai maksimal sebesar 16 dan minimal sebesar 2 yang salah satunya ditunjuk sebagai presiden direktur sesuai dengan peraturan yang berlaku. CEOTENURE menghasilkan rata-rata sebesar 2,474 (pembulatan menjadi 2,5) atau masa jabatan presiden direktur menjabat selama 7-9 tahun. Meskipun peraturan mengenai masa jabatan direksi yang diatur di Indonesia maksimal selama 10 tahun, namun sebanyak 31 perusahaan $(10,54 \%$ sampel $)$ menunjukan presiden direktur telah menjabat selama 15 tahun. FOREIGN menghasilkan rata-rata sebesar 0,128 dan sebanyak 168 perusahaan (57\% sampel) tidak mempunyai direksi dengan kewarganegaraan asing. Nilai dari FOREIGN memiliki nilai maksimal sebesar 1, yaitu seluruh direksi ditempati oleh direksi dengan kewarganegaraan asing yang dimiliki oleh PT Eratex Djaja Tbk. Hal ini dikarenakan perusahaan merupakan perusahaan Penanaman Modal Asing (PMA), sehingga direksi perusahaan dapat ditetapkan oleh pemilik modal asing berdasarkan orang yang dipercayainya (UU No. 1 / 1967 pasal 9).

\section{Hasil Uji Regresi}

Tabel 3 Hasil Uji Regresi ROA

\begin{tabular}{|l|c|c|c|}
\hline \multirow{2}{*}{ Variabel } & \multicolumn{3}{|c|}{ Model ROA } \\
\cline { 2 - 4 } & Koef. & $\mathbf{t}$ & $\mathbf{P}>|\mathbf{t}|$ \\
\hline BOARDSIZE & 0,007 & 8,5 & $0,000^{*}$ \\
\hline CEOTENURE & 0,001 & 1,08 & 0,279 \\
\hline FOREIGN & 0,0329 & 6,14 & $0,000^{*}$ \\
\hline AGE & 0,0009 & 11,2 & $0,000^{*}$ \\
\hline LEV & $-0,001$ & $-25,1$ & $0,000^{*}$ \\
\hline SIZE & $7,91 \mathrm{e}^{-9}$ & 3,83 & $0,000^{*}$ \\
\hline GROWTH & 0,003 & 1,24 & 0,215 \\
\hline CONS & 0,0108 & 0,66 & 0,508 \\
\hline Prob>F & & 0,000 & \\
\hline Adj R-Sq & & 0,1981 & \\
\hline
\end{tabular}

Keterangan : Tingkat signifikansi : $* 5 \%$ Sumber: data diolah, 2020 
Tabel 4

Hasil Uji Regresi ROE

\begin{tabular}{|l|c|c|c|}
\hline \multirow{2}{*}{ Variabel } & \multicolumn{3}{|c|}{ Model ROE } \\
\cline { 2 - 4 } & Koef. & $\mathbf{t}$ & $\mathbf{P}>|\mathbf{t}|$ \\
\hline BOARDSIZE & 0,0198 & 3,11 & $0,002^{*}$ \\
\hline CEOTENURE & $-0,003$ & $-0,52$ & 0,602 \\
\hline FOREIGN & 0,076 & 1,26 & 0,208 \\
\hline AGE & 0,0019 & 2,18 & $0,029^{*}$ \\
\hline LEV & $-0,001$ & $-0,76$ & 0,449 \\
\hline SIZE & $2,22 \mathrm{e}^{-8}$ & 0,81 & 0,418 \\
\hline GROWTH & 0,0015 & 0,18 & 0,854 \\
\hline CONS & $-0,096$ & $-1,56$ & 0,12 \\
\hline Prob>F & & 0,0001 & \\
\hline Adj R-Sq & & 0,0196 & \\
\hline Ketergan :
\end{tabular}

Keterangan : Tingkat signifikansi : *5\%

Sumber: data diolah, 2020

Hasil pengujian statistik $\mathrm{F}$ menunjukkan variabel independen memiliki pengaruh signifikan terhadap kedua variabel dependen, ROA dan ROE karena nilai Prob $>\mathrm{F}$ berada dibawah 0,05 . Uji koefisien determinasi menunjukkan variabel independen mampu menjelaskan ROA sebesar $19,81 \%$ dan sisanya sebesar $80,19 \%$ dijelaskan oleh variabel lain yang tidak diteliti dalam penelitian ini. Untuk variabel ROE, memiliki nilai koefisien determinasi yang lebih rendah dibandingkan ROA. Variabel independen hanya mampu menjelaskan variabel ROE sebesar 1,96\% dan sisanya sebesar $98,04 \%$ dijelaskan oleh variabel lain.

\section{Pengaruh Jumlah Direksi Terhadap Kinerja Perusahaan}

Hasil pengujian jumlah direksi terhadap ROA dan ROE menunjukkan hasil positif signifikan dan sejalan dengan RDT yang menyatakan direksi merupakan aset paling penting bagi perusahaan yang bertanggung jawab dalam menjaga keberlangsungan usaha perusahaan (Hillman et al., 2009). Jumlah direksi yang banyak dapat lebih efisien untuk melakukan monitoring dalam mencegah fraud (Johl et al., 2015) dan memiliki pengetahuan yang lebih luas untuk memberikan ide dan perspektif dalam 244 pengambilan keputusan untuk meningkatkan kinerja perusahaan (Vu et al., 2018). Ahmadi, Nakaa dan Bouri (2018) menyatakan jumlah direksi yang banyak dalam suatu perusahaan dapat mengurangi konflik kepentingan pribadi dan anggota direksi berusaha keras untuk memperbaiki kinerja perusahaan. Namun, Pfeffer (1972) menemukan bahwa jumlah direksi dalam suatu perusahaan tergantung dari kebutuhan perusahaan dan lingkungan eksternalnya dan kinerja perusahaan tahun sebelumnya (Pearce \& Zahra, 1992).

Zion dan Markarian (2018) menemukan hasil yang positif signifikan antara jumlah direksi dengan kinerja perusahaan pada jumlah direksi antara 5-9 orang, tetapi ketika akan terjadi penurunan kinerja jika lebih dari 9 orang. Hasil penelitian ini berbeda dengan jumlah optimal direksi pada setiap industri perusahaan yang dikategorikan berdasarkan Jakarta Stock Industrial Classification (JASICA). Pada industri agrikultur dan barang konsumsi, menunjukkan jumlah direksi yang optimal adalah masing-masing sebanyak 5-8 orang dan 9-12 orang untuk menghasilkan kinerja ROA dan ROE optimal. Jumlah direksi optimal sebanyak 7-9 orang diperlukan untuk mencapai ROA optimal dan 4-6 orang untuk mencapai ROE optimal pada industri pertambangan. Pada basic industri dan industri kimia jumlah direksi yang optimal adalah sebanyak 10-12 orang untuk menghasilkan kinerja ROA dan ROE yang optimal, sedangkan industri infrastruktur, utilitas dan transportasi hanya memerlukan 2 orang direksi. Industri miscellaneous membutuhkan jumlah direksi sebanyak 7-12 orang untuk menghasilkan kinerja ROA dan ROE yang optimal. Pada industri properti, real estate dan jasa konstruksi serta yaitu industri perdagangan, jasa dan investasi memerlukan 4-6 orang direksi untuk menghasilkan kinerja ROA yang optimal dan 7-9 orang untuk menghasilkan kinerja ROE yang optimal. Hasil yang berbeda-beda tiap industri, sejalan dengan penelitian Pfeffer (1972), 
mengenai penentuan jumlah direksi bergantung dengan kebutuhan dari masingmasing perusahaan. Pada penelitian ini juga membukti bahwa adanya inverted $u$-shaped effect sama seperti pada penelitian yang dilakukan oleh Zion dan Markarian (2018), yang menunjukkan bahwa jumlah direksi akan mempengaruhi kinerja perusahaan hanya sampai pada jumlah yang optimal pada setiap industri.

\section{Pengaruh Masa Jabatan Presiden Direktur Terhadap Kinerja Perusahaan}

Hasil uji regresi masa jabatan presiden direktur menunjukkan bahwa masa jabatan presiden direktur tidak mempengaruhi kinerja perusahaan dan hipotesis kedua ditolak. Meskipun secara rata-rata masa jabatan presiden direktur di Indonesia dijabat antara 7-9 tahun (berdasarkan tabel 4.2) dan menunjukkan bahwa presiden direktur tersebut loyal terhadap perusahaan seperti teori stewardship, namun nyatanya masa jabatan presiden direktur tidak memberikan pengaruh terhadap kinerja perusahaan di Indonesia.

Kinerja perusahaan tidak dipengaruhi oleh masa jabatan presiden direktur karena baik presiden direktur dengan masa jabatan yang lama maupun pendek memiliki tugas dan tanggung jawab yang sama untuk mengelola kinerja perusahaan. Presiden direktur yang baru diangkat akan merasa cemas terhadap masa depan dan keberlangsungan hidup di suatu perusahaan dibandingkan dengan presiden direktur yang telah lama menjabat pada perusahaan yang sama, sehingga takut untuk mengambil resiko dalam mengambil keputusan (Naseem et al., 2019). Sedangkan, presiden direktur yang lama menjabat di sebuah perusahaan akan menyebabkan struktur perusahaan menjadi kaku dan sulit untuk mengubah strategi yang telah digunakan, meskipun Ia dianggap telah mengetahui kondisi perusahaan (Kwalomine, 2018).

Oleh karena itu, semakin panjang masa jabatan presiden direktur tidak memberikan pengaruh terhadap kinerja perusahaan. Hal ini dikarenakan akan membentuk paradigma dalam mengelola perusahaan dan enggan untuk mengganti strategi dengan adanya perkembangan informasi (McClelland, Barker \& Oh, 2012). Masa jabatan yang panjang juga akan menghilangkan keinginan presiden direktur untuk memajukan karirnya dan lebih sulit untuk bergerak dalam memajukan kinerja perusahaan $(\mathrm{Ng} \&$ Feldman, 2013) karena cenderung menolak dan menghindari risiko yang akan dihadapi perusahaan (Luo, Kanuri \& Andrews, 2014). Presiden direktur yang telah lama menjabat di perusahaan juga cenderung akan menghindari perselisihan karena memiliki hubungan yang dekat dengan direksi lain (Kagzi \& Guha, 2018). Selain itu, untuk mencapai kinerja perusahaan, setiap direksi memiliki posisi yang setara dan tidak hanya dipengaruhi oleh presiden direktur saja (Kartikaningdyah \& Putri, 2017).

\section{Pengaruh Direksi Asing Terhadap Kinerja Perusahaan}

Kehadiran direksi dengan kewarganegaraan asing untuk tujuan independensi dapat menghasilkan hubungan yang positif signifikan terhadap ROA, namun tidak mempengaruhi ROE. Kehadiran direksi dengan kewarganegaraan asing di dalam suatu perusahaan juga dipengaruhi oleh faktor investor asing sehingga dapat melindungi kepentingan investor asing (Oxelheim \& Randoy, 2003). Selain itu, kehadiran direksi dapat menjadi tanda bahwa perusahaan dikelola secara profesional dan dapat menarik investor global untuk berinvestasi karena kehadirannya dapat menyelaraskan kepentingan pemegang saham dan perusahaan (Oxelheim \& Randoy, 2001). Teori RDT mendukung adanya keberagaman dalam anggota direksi pada suatu perusahaan (Pfeffer \& Salancik, 2003) dengan latar belakang, budaya, keterampilan, pengalaman, dan koneksi 
yang luas (Ujunwa, 2012). Hubungan positif ini terjadi karena keragaman kewarganegaraan direksi akan memberikan perspektif kognitif yang berbeda (Temprano \& Gaite, 2009). Hal ini sesuai dengan harapan pemerintah dalam mengeluarkan Perpres No. 20 tahun 2018 yang mengatur penggunaan tenaga kerja asing di Indonesia. Dengan dikeluarkannya peraturan tersebut, pemerintah mengharapkan dengan adanya tenaga kerja asing dapat terjadi transfer of knowledge, skill, dan teknologi, meningkatkan investasi asing dalam penyertaan modal, serta memperluas tenaga kerja (Zuhdi, Nugroho \& Jannah, 2019). Namun, kehadiran direksi dengan kewarganegaraan asing tidak memberikan pengaruh terhadap ROE perusahaan karena direksi tersebut tidak memiliki kekuatan untuk mempengaruhi pengambilan keputusan strategis dalam rangka meningkatkan kinerja perusahaan (Zakaria, Purhanudin, Palanimally, 2014) karena dari hasil data menunjukkan bahwa 7 dari 8 sektor memposisikan direksi asing sebagai direktur operasional, hanya pada industri infrastruktur, utilitas, dan transportasi yang mayoritas direksi asingnya menduduki posisi direktur keuangan.

Setiap industri perusahaan memiliki persentase optimal direksi kewarganegaraan asing yang berbeda-beda. Industri agrikultur merupakan industri dengan persentase direksi kewarganegaraan asing terkecil dengan jumlah optimal sebanyak $14,3 \%$ dari jumlah direksi untuk kedua kinerja perusahaan. Jumlah direksi dengan kewarganegaraan asing yang dapat menghasilkan kinerja ROA yang optimal pada industri barang konsumsi dan industri miscellaneous sebesar 26-50\%, sedangkan untuk ROE dibutuhkan masing-masing sebesar $51-75 \%$ dan kurang dari $25 \%$. Pada basic industry dan kimia dan industri property, real estate dan jasa konstruksi membutuhkan 26-50\% direksi dengan kewarganegaraan asing untuk menghasilkan kinerja ROA dan ROE yang optimal. Persentase direksi dengan kewarganegaraan asing sebesar $51-75 \%$ menjadi persentase terbesar dari jumlah direksi dengan kewarganegaraan yang dibutuhkan pada industri pertambangan dan industri perdagangan, jasa dan investasi untuk menghasilkan kinerja perusahaan yang optimal.

Mayoritas perusahaan di Indonesia merupakan perusahaan yang memiliki perusahaan dengan penanam modal asing dan industri barang konsumsi merupakan industri dengan kepemilikan PMA terbesar dibandingkan dengan industri lain-nya, sebesar 59,38\%, yang menyebabkan persentase jumlah direksi kewarganegaraan asing di perusahaan menjadi besar. Hal ini juga dikarenakan beberapa perusahaan industri barang konsumsi merupakan perusahaan perwakilan dari head office luar negeri, seperti PT Unilever Indonesia, PT Akasha Wira International, PT Mandom Indonesia, dll. Namun, kehadiran direksi dengan kewarganegaraan asing tidak hanya terkait dengan perusahaan PMA, melainkan perusahaan Penanaman Modal Dalam Negeri (PMDN) juga ada yang memiliki direksi dengan kewarganegaraan asing, seperti PT Hanjaya Mandala Sampoerna, PT. Adaro Energy, PT. Petrosea, dll. Hadirnya tenaga kerja asing, termasuk yang akan menjabat sebagai direktur, diharapkan dapat meningkatkan kualitas tenaga kerja yang ada di Indonesia, baik dari pengetahuan, keterampilan, dan kompetensi (Zuhdi et al., 2019).

\section{Pengaruh Variabel Kontrol Terhadap Kinerja Perusahaan}

Pengujian regresi variabel kontrol terhadap kinerja perusahaan juga dilakukan. Pengaruh umur perusahaan terhadap kinerja ROA dan ROE menunjukkan hasil positif signifikan. Hal ini dikarenakan semakin lama perusahaan berdiri, perusahaan akan lebih mengetahui kemampuan dan cara yang tepat untuk menjalankan kegiatan operasional perusahaan yang lebih efektif (Omondi \& Muturi, 2013) dan meningkatkan produktivitas dalam 
menghasilkan laba perusahaan yang lebih tinggi dan berdampak pada ukuran perusahaan yang semakin besar, rasio utang perusahaan akan semakin rendah, dan rasio ekuitas lebih tinggi (Hunjra, Chani, Javed, Naeem \& Ijaz, 2014). Leverage menghasilkan pengaruh negatif signifikan terhadap ROA karena perusahaan yang lebih mengandalkan aset mereka dibandingkan mengambil pinjaman dari eksternal dapat menghasilkan lebih banyak laba karena memiliki rasio leverage yang lebih rendah (Ahmad, Salman \& Shamsi, 2015). Sedangkan ROE tidak dipengaruhi oleh leverage. Ukuran perusahaan juga memiliki pengaruh positif terhadap ROA tetapi tidak mempengaruhi ROE. Perusahaan dengan total aset yang tinggi dapat lebih efektif dalam menurunkan biaya produksi (Dogan, 2013) dan dapat mencegah kebangkrutan karena akan lebih mudah mendapatkan pinjaman (Sritharan, 2018). Pengujian pertumbuhan perusahaan menunjukkan bahwa pertumbuhan perusahaan tidak memberikan pengaruh terhadap ROA dan ROE, karena pertumbuhan penjualan lebih menjelaskan kepada peluang perusahaan dibandingkan dengan profitabilitas (Ting, Kweh \& Chan, 2014) dan tidak dapat digunakan untuk mengukur efisiensi perusahaan (Pham, Tran \& Nguyen, 2018).

\section{Simpulan dan Saran}

\section{Simpulan}

Seluruh perusahaan di Indonesia telah menaati peraturan yang berlaku dengan jumlah direksi lebih dari 2 orang, salah satunya akan menjabat sebagai presiden direktur. Hasil dari penelitian menunjukkan bahwa jumlah direksi berpengaruh positif signifikan terhadap ROA dan ROE. Hubungan yang positif ini menandakan bahwa jumlah direksi yang banyak di perusahaan akan memudahkan melakukan pengawasan yang dapat mencegah terjadinya fraud seperti kepentingan konflik kepentingan pribadi, memberikan sudut pandang maupun ide yang beragam dalam pengambilan keputusan, dan meningkatkan koneksi antara perusahaan dengan lingkungan eksternal. Berdasarkan penelitian ini menghasilkan jumlah direksi optimal adalah sebanyak 4-6 orang untuk meningkatkan ROA dan 7-9 orang untuk meningkatkan ROE.

Secara rata-rata, masa jabatan presiden direktur di Indonesia selama $7-9$ tahun dan dapat dikatakan sebagian besar perusahaan Indonesia patuh terhadap peraturan Undang-Undang Republik Indonesia No. 19 tahun 2003 pasal 16 ayat 4 dan POJK no. 33/POJK.04/2014 pasal 3 yang mengatur masa jabatan direktur adalah 5 tahun dan dapat diangkat kembali untuk 1 kali masa jabatan. Namun, loyalitas presiden direktur terhadap perusahaan tidak memberikan dampak terhadap kinerja perusahaan. Hal ini dikarenakan presiden direktur cenderung menolak dan menghindari risiko maupun perselisihan. Selain itu, kinerja perusahaan dipengaruhi oleh seluruh direksi bukan hanya presiden direktur saja.

Kehadiran direksi dengan kewarganegaraan asing untuk mendukung independensi perusahaan di perusahaan Indonesia masih sangat sedikit, terdapat 168 perusahaan yang tidak memiliki direksi asing. Dilihat dari hasil penelitian ini direksi dengan kewarganegaraan asing berpengaruh positif signifikan terhadap ROA. Kehadiran direksi dengan kewarganegaraan asing dapat meningkatkan kinerja perusahaan karena adanya perbedaan latar belakang budaya mencangkup perspektif, pengetahuan, dan keahlian yang dapat memberikan alternatif dalam pengambilan keputusan. Sedangkan, kehadiran direksi dengan kewarganegaraan asing tidak mempengaruhi ROE karena dapat menghambat pengambilan keputusan, menimbulkan perbedaan pendapat, bahkan dapat memicu munculnya konflik antar anggota yang berdampak pada penurunan kinerja perusahaan. Selain itu, peran direksi 
asing yang mayoritas ditugaskan sebagai direksi operasional akan sulit mempengaruhi kebijakan strategis keuangan yang terkait dengan permodalan dan kinerja ROE. Berdasarkan penelitian, persentase direksi dengan kewarganegaraan asing yang optimal untuk meningkatkan ROA adalah sebesar 26\%-50\%. Sedangkan untuk meningkatkan ROE persentase direksi dengan kewarganegaraan asing yang optimal adalah sebesar 51\%-75\%.

\section{Implikasi}

Penelitian ini memberikan beberapa implikasi kepada berbagai pihak. Bagi akademisi, penelitian selanjutnya dapat meneliti karakteristik direksi yang lebih beragam, seperti dengan menambahkan latar belakang pendidikan terakhir direksi, pengalaman kerja direksi, ataupun umur direksi yang dapat menjadikan penelitian lebih detail yang dapat mempengaruhi kinerja, sedangkan untuk pembaca dapat dijadikan bukti empiris adanya pengaruh karakteristik direksi terhadap kinerja keuangan di perusahaan. Faktor karakteristik direksi dengan kualifikasi kinerja yang baik, seperti perusahaan dengan jumlah direksi sebanyak 7-9 orang, presiden direktur menjabat selama 7-9 tahun, persentase direksi dengan kewarganegaraan asing sebesar 51-75\% dalam suatu perusahaan dapat dijadikan bahan pertimbangan investor agar hak dari investor tetap terpenuhi dan tidak merasa khawatir terhadap perusahaan yang diinvestasikan. Bagi perusahaan, diharapkan dapat mempertimbangkan karakteristik direksi yang tepat sesuai dengan kebutuhan perusahaan. Selain itu, pemerintah juga dapat mempertimbangkan mengenai peraturan yang berlaku mengenai masa jabatan presiden direktur sesuai dengan industri perusahaan.

\section{Keterbatasan}

Keterbatasan dalam penelitian ini, adalah:

- Penelitian ini hanya menggunakan variabel dependen kinerja perusahaan yang keduanya diukur menggunakan basis akuntansi, yaitu ROA dan ROE.

- Penelitian ini menggunakan seluruh sektor, kecuali industri keuangan, sebagai sampel observasi sehingga sulit untuk menentukkan jumlah direksi, lama masa jabatan presiden direktur, dan proporsi direksi dengan kewarganegaraan asing yang optimal, disebabkan oleh kebutuhan karakteristik direksi pada setiap industri berbeda-beda.

\section{Saran}

Bagi penelitian selanjutnya, dapat mempertimbangkan beberapa saran sebagai berikut:

- Peneliti selanjutnya dapat menggunakan kinerja perusahaan yang diukur dengan market performance sebagai perbandingan dari operating dan financial performance, seperti contohnya dapat menggunakan earning per shares (EPS), Tobin's Q, dan market to book value.

- Bagi peneliti selanjutnya, jika ingin mendapatkan karakteristik yang optimal terhadap kinerja perusahaan akan lebih baik menggunakan satu industri saja agar hasil lebih akurat. 


\section{Daftar Pustaka}

Ahmad, N., Salman, A. \& Shamsi, A.F. (2015). Impact of Financial Leverage on Firms' Profitability: An Investigation from Cement Sector of Pakistan. Research Journal of Finance and Accounting, 6(7).

Ahmadi, A., Nakaa, N. \& Bouri, A. (2018). Chief Executive Officer attributes, board structures, gender diversity and firm performance among French CAC 40 listed firms. Research in International Business and Finance, 44, 2018-226.

Aldrich, H.E., \& Pfeffer,J. (1976). Environments of Organizations. Annual Review of Sociology, 79-44.

Anton, F. (2010). Menuju Teori Stewardship Management. Majalah Ilmiah Informatika, 1(2), 61-80.

Anwar, R. (2018). Pengaruh Kepuasan Kerja Dan Loyalitas Kerja Terhadap Organizational Citizenship Behavior (Ocb) Pada Kinerja Karyawan Pt.hm.sampoerna,tbk Baturaja Timur Sumatera Selatan. Jurnal Manajemen Dan Bisnis Sriwijaya, 16(2), 110-121. DOI: 10.29259/jmbs.v16i2.6950.

Arora, A. \& Sharma, C. (2016). Corporate governance and firm performance in developing countries: evidence from India.Corporate Governance, 16(2).

Bachiller, P., Giorgino, M. C., \& Paternostro, S. (2014). Influence of board of directors on firm performance: Analysis of family and non-family firms. International Journal of Disclosure and Governance, 12(3), 230-253.

Beasley, M. (1996). An empirical analysis of the relation between the board of director composition and financial statement fraud. The Accounting Review, 71(4), 443-465.

Cadbury, A. (n.d.). The Financial Aspects of Corporate Governance. The Financial Aspects of Corporate
Governance. London: Great Britain by Burgess Science Press.

Cherrington, D.J. (1989). Organizational behavior: The management of individual and organizational performance. Allyn \& Bacon.

Choi, H. M., Sul, W., \& Min, S. K. (2012). Foreign board membership and firm value in Korea. Management Decision, 50(2), 207-233. DOI: $10.1108 / 00251741211203533$.

Coles, J. L., Daniel, N.D. \& Naveen, L. (2008). Does one size fit all? Journal of Financial Economics, 87(2), 329-56.

Cook, M. \& Burress, M. (2013). The Impact of CEO Tenure on Cooperative Governance. Managerial and Decision Economics, 34.

Donaldson, L. \& Davis, J.H. (1991). Stewardship Theory or Agency Theory: CEO Governance and Shareholder Returns. Australian Journal of Management, 16(1), 4964.

Donaldson, L., \& Davis, J.H. (1989). CEO governance and shareholder returns: Agency theory or stewardship theory. Paper presented at the annual meeting of the Academy of Management, Washington, DC.

Donaldson, L. \& Davis, J.H. (1994). Boards and Company Performance Research Challenges the Conventional Wisdom. Corporate Governance: An International Review, 2, 151-160.

Donaldson, T. \& Preston, L.E. (1995). The stakeholder theory of the corporation: concepts, evidence, and implications. Academy of Management Review, 20(1), 65-91.

Dogan, M. (2013). Does Firm Size Affect The Firm Profitability? Evidence from Turkey. Research Journal of Finance and Accounting, 4(4). 
Elegido, J. M. (2013). Does it make sense to be a loyal employee? Journal of Business Ethics, 116(3): 495-511

Ferraz, D. P., Lopes,I. T. \& Kopliku, A. (2018). Can board diversity and choice of director enhance profitability?. Int. J. Business Performance Management, 19(3).

Gillan, S.L. \& Starks, L.T. (1998). A survey of shareholder activism: motivation and empirical evidence. Contemporary Finance Digest, 2 (3), 10-34.

Gujarati, D. N. \& Porter, D. (2009). Basic Econometrics (5th ed.). Boston:McGraw-Hill Irwin.

Gomes, L. \& Sutanto, E. (2017). Pengaruh Motivasi Kerja dan Loyalitas Karyawan Terhadap Kinerja Karyawan di CV Hartono Flash Surabaya. AGORA, 5(3).

Hartnell, C. A., Kinicki, A. J., Lambert, L. S., Fugate, M., \& Corner, P. D. (2016). Do similarities or differences between CEO leadership and organizational culture have a more positive effect on firm performance? A test of competing predictions. Journal of Applied Psychology, 101(6), 846-861. DOI: $10.1037 /$ apl0000083

Hillman, A. \& Dalziel, T. (2003). Boards of Directors and Firm Performance: Integrating Agency and Resource Dependence Perspectives. Academy of Management Review, 28(3), 383396.

Hillman, A., Withers, M., \& Collins, B. (2009). Resource Dependence Theory: A Review. Journal of Management, 35(6), 1404-1427.

Hoechle, D. (2007). Robust standard errors for panel regressions with crosssectional dependence. The Stata Journal, 7(3), 281-312.

Hossain, M., Cahan, S. F., \& Adams, M. B. (2000). The investment opportunity set and the voluntary use of outside directors: New Zealand evidence.
Accounting and Business Research, 30(4), 263-273.

Hunjra, A. I, Chani, M. I., Javed, S., Naeem, S. and Ijaz, M.S. (2014). Impact of Micro Economic Variables on Firms Performance. International Journal of Economics and Empirical Research. 2(2), 6573.

Hutchinson, M. \& Gul, F.A. (2004). Investment opportunity set, corporate governance practices and firm performance. Journal of Corporate Finance, 10, 595-614.

Jefri, R. (2018). Teori Stewardship Dan Good Governance. Jurnal Riset Unibos Makassar, 4(3)

Jhunjhunwala, S. \& Mishra, R.K. (2012). Board diversity and corporate performance: the Indian evidence. IUP Journal of Corporate Governance, 11(3), 71-79.

Johl, S. K., Kaur, S. \& Cooper B. J. (2015). Board Characteristics and Firm Performance: Evidence from Malaysian Public Listed Firms. Journal of Economics, Business and Management, 3(2).

Judge, W.Q. \& Zeithaml, C.P. (1992).Institutional and strategic choice perspectives on board involvement in the strategic decision process. The Academy of Management Journal, Vol. 35 No. 4, pp. 766-794.

Kagzi, M. \& Guha, M. (2018). Does board demographic diversity influence firm performance? Evidence from Indian-knowledge intensive firms. Benchmarking: An International Journal, 25(3), 2018.

Kartikaningdyah, E. \& Putri, R. (2017). Pengaruh Tax Avoidance dan Board Diversity terhadap Kinerja Perusahaan dalam Perspektif Corporate Governance. Journal of Applied Accounting and Taxation. 2(2), 114-122. 
Kaur, R. \& Singh, B. (2018). CEO's Characteristics and Firm Performance: A Study of Indian Firms. Indian Journal of Corporate Governance, Vol. 11, No. 2, pp. 116.

DOI: $10.1177 / 0974686218806714$

Khan, I., Khan, I. \& Senturk, I. (2019). Board diversity and quality of CSR disclosure: evidence from Pakistan. Corporate Governance, Emerald Publishing Limited, ISSN 14720701

Khanchel, I. (2007). Corporate governance: measurement and determinate analysis. Managerial Auditing Journal, 22(8), 740-760.

KNKG. (2006). Pedoman umum Good Corporate Governance Indonesia. academia.edu. Retrieved from https://www.academia.edu/3733687 0/1_-_KNKG_Pedoman_CG_20061.pdf

Kwalomine, A. (2018). Pendidikan, Masa Jabatan Direktur Utama dan Pengungkapan Corporate Social Responsibility (CSR). Jurnal Riset Akuntansi Terpadu, 11(1), 72-82.

Ling, T. P., Chiek, A. N., \& Seong, L. C. (2016). Foreign ownership, foreign directors and the profitability of Malaysian listed companies. Social and Behavioral Science 2019, pp. 580-588.

DOI:10.1016/j.sbspro.2016.05.037

Luo, X., Kanuri, V. \& Andrews, M. (2014). How does CEO Tenure Matter? The Mediating Role of Firm-Employee and Firm - Customer Relationships. Strategic Management Journal, 35 (4).

McClelland, P., Barker, V., \& Oh, W. (2012). CEO career horizon and tenure: future performance implications under different contingencies. Journal of Business Research, 65(9), 1387-1393.

Merendino, A. \& Melville, R. (2018). The board of director and firm performance: empirical evidence from listed companies. Corporate Governance, 19(3), 508-551.

Mishra, R. K. \& Kapil, S. (2017). Board Characteristics and Firm Value for Indian Companies. Journal of Indian Business Research, 10(1), 2-32.

Muttakin, M., Khan, A. \& Subramaniam, N. (2012). Board structure and firm performance: Evidence from an emerging economy. Academy of Taiwan Business Management Review, 8(2), 1-13.

Naseem, M., Lin, J., Rehman, R., Ahmad, M., \& Ali, R. (2019). Does capital structure mediate the link between CEO characteristics and firm performance?

Management Decision, 58(1), 164-181.

Ng, T. \& Feldman, D. (2013). Does longer job tenure help or hinder job performance?. Journal of Vocational Behavior, 83 (3), 305 - 314.

Omondi, M. \& Muturi, W. (2013). Factors Affecting the Financial Performance of Listed Companies at the Nairobi Securities Exchange in Kenya. Research Journal of Finance and Accounting, 4(15).

Oxelheim, L. \& Randoy, T. (2001). The Impact of Foreign Board Membership on Firm Value. Institute of Economic Research.

Oxelheim, L.H. \& Randoy, T. (2003). The impact of foreign membership on firm value. Journal of Banking and Finance, 27(12), 615-31.

Palaniappan, G. (2017). Determinants of Corporate Financial Performance Relating to Board Characteristics of Corporate Governance in Indian Manufacturing Industry. European Journal of Management and Business Economics, 26(1), 67-85.

Pearce, J. \& Zahra, S. (1989). Boards of directors and corporate Financial Performance: A Review and Interactive Model. Journal of Management, 15(2), 291-334. 
Pearce, J. A. \& Zahra, S. A. (1992). Board composition from a strategic contingency perspective. Journal of Management Studies, 29, 411-438.

Petria, N., Capraru, B. \& Ihnatov, I. (2015). Determinants of banks profitability: evidence from EU 27 Banking Systems. Procedia Economics and Finance, 20, 518 - 524.

Pham, C. , Tran, Q. \& Nguyen, L. (2018). Effects of Internal Factors on Financial Performance of Listed Construction - Material Companies: The Case of Vietnam. Research Journal of Finance and Accounting, 9 (10).

Presiden Republik Indonesia. (2003). Undang- Undang Republik Indonesia Nomor 19 Tahun 2003 tentang Badan Usaha Milik Negara. bpkp.go.id. Retrivied from http://www.bpkp.go.id/uu/filedownload /2/40/264.bpkp

Presiden Republik Indonesia. (2007). Undang-Undang Republik Indonesia Nomor 40 Tahun 2007 tentang Perseroan Terbatas. ojk.go.id. Retrieved from https://www.ojk.go.id/sustainablefinance/id/peraturan/undangundang/Documents/5.\%20UU-402007\%20PERSEROAN\%20TERBAT AS.pdf

Presiden Republik Indonesia. (2018). Peraturan Presiden Nomor 20 Tahun 2018 tentang Penggunaan Tenaga Kerja Asing. Hukumonline.com. Retrievied from https://m.hukumonline.com/pusatdata/d etail/1t5ac4749a91896/node/534/peratu ran-presiden-nomor-20-tahun-2018

Pfeffer, J. (1972). Size and Composition of Corporate Boards of Directors: The Organization and its Environment. Administrative Science Quarterly, 17(2), 218-228.

Pfeffer, J., \& Salancik, G. R. (1978). The external control of organizations: A resource dependence perspective. New York: Harper \& Row.

Primadhyta, S. (2017). OJK: Praktik GCG Perusahaan Indonesia Masih Tertinggal. cnnindonesia.com. Retrieved from https://www.cnnindonesia.com/ekonom i/20170920070153-78-242846/ojkpraktik-gcg-perusahaan -indonesia-masih-tertinggal

Ravinder, D. \& Anitha,M. (2013). Financial Analysis - A Study. IOSR Journal of Economics and Finance (IOSR-JEF), 2(3), 10-22.

Raymond K., Paul M. \& Jaeyoung Kang. (2010). Board of Director: Composition and Financial Performance In A Sarbanes-Oxley World. Academy of Business and Economics Journal, 10 (5), 5-74.

Salehi, M., Tahervafaei, M. \& Tarighi, H. (2017). The effect of characteristics of audit committee and board on corporate profitability in Iran. Journal of Economic and Administrative Sciences, 34(1), 71-88

Shukla, M. (2018). National Diversity on Board and Firm Performance-Evidence from India. SCMS Journal of Indian Management, 15(3), 29-41

Singh, V. (2007), "Ethnic diversity on top corporate boards: a resource dependency perspective", International Journal of Human Resource Management, Vol. 18 No. 12, pp. 2128-2146.

Sritharan, V. (2018). Firm Size Influence on Profitability of Sri Lanka Diversified Holdings Firms. International Journal of Advanced Research in Management and Social Sciences, 7(6).

Temprano, M. \& Gaite, F. (2019). Types of director, board diversity and firm performance. Corporate Governance, 20 (2), 324-342.

Ting, I. , Kweh, Q. \& Chan, Y. Does Organizational Growth Contribute to Profitability? Evidence from Malaysian 
Public Listed Companies. International Journal of Business and Society, 15(2), 267-276.

Tomic, I., Tesic, Z., Kuzmanovic, B., \& Tomic, M. (2018). An empirical study of employee loyalty, service quality, cost reduction and company performance. Economic ResearchEkonomska Istraživanja, 31(1), 827846.

Trivedi, C. (2015). Comparing the difference in firm performance between firms with and without foreign board membership. Published by ProQuest LLC.

Ujunwa, A. (2012). Board characteristics and the financial performance of Nigerian quoted firms. Corporate Governance International Journal of Business Society, 12(5), 656-674.

Vafeas, N. (2003). Length of Board Tenure and Outside Director Independence. Journal of Business Finance \& Accounting, 30(7-8), 10431064.

Vu, M. C., Phan T. T. \& Le N. T. (2018). Relationship between board ownership structure and firm financial performance in transitional economy: The case of Vietnam. Research in International Business and Finance, Vol. 45, pp.512-528.

Wintoki, M. B., Linck, J. S., \& Netter, J. M. (2012). Endogeneity and the dynamics of internal corporate governance. Journal of Financial Economics, 105(3), 581-606.

Yasser, Q., Mamun, A., \& Seamer, M. (2016). Do Corporate Boards Affect Firm Performance? New Evidence from an Emerging Economy. International Journal of Productivity and Performance Management, 66(6), 724-741.

Yermack, D. (1996). Higher market valuation of companies with a small board of directors. Journal of Financial Economics, 40, 185-212.
Zakaria, Z., Purhanudin, N., \& Palanimally, Y. (2014). Board Governance and Firm Performance: A Panel Data Analysis. Journal of Business Law and Ethics, 2(1), 01-12.

Zion, U.B. \& Markarian, G. (2018). Board Size, Crisis, and Firm Performance: Evidence from Banks. International Journal of Economics and Finance, $10(4)$.

Zuhdi, S., Nugroho, W. \& Jannah, R. (2019). Meninjau Peraturan Presiden Nomor 20 Tahun 2018 Sebagai Rangka Perbaikan Hukum Perlindungan Tenaga Kerja Indonesia. Jurnal Law and Justice, 4(1). 


\section{Lampiran}

\begin{tabular}{|c|c|c|c|c|}
\hline \multicolumn{5}{|c|}{$\begin{array}{c}\text { Lampiran 1 } \\
\text { Jumlah Optimal Direksi terhadap ROA } \\
\text { dan } \\
\text { ROE }\end{array}$} \\
\hline Sector & $\begin{array}{l}\text { Jumlah } \\
\text { Direksi }\end{array}$ & $\begin{array}{l}\text { Jumbh } \\
\text { Observ asi }\end{array}$ & $\begin{array}{l}\text { Avg } \\
\text { ROA }\end{array}$ & $\begin{array}{l}\text { Avg } \\
\text { ROE }\end{array}$ \\
\hline \multirow{4}{*}{ Agriculture } & $1-2$ & 0 & 0 & 0 \\
\hline & $3-4$ & 13 & -0.012 & -0.025 \\
\hline & \begin{tabular}{|l|}
$5-6$ \\
\end{tabular} & 57 & 0.973 & -0.017 \\
\hline & $7-8$ & 20 & 0.035 & 0.058 \\
\hline \multirow{4}{*}{ Consumer Goods Industry } & $1-4$ & 91 & 0.043 & 0.173 \\
\hline & $5-8$ & 72 & 0.143 & 0.231 \\
\hline & $9-12$ & 23 & 0.159 & 0.403 \\
\hline & $13-16$ & 6 & 0.121 & 0.156 \\
\hline \multirow{4}{*}{ Mining } & $1-3$ & 40 & 0 & -0.046 \\
\hline & $4-6$ & 116 & 0.023 & -0.002 \\
\hline & $7-9$ & 20 & 0.106 & -0.633 \\
\hline & $10-12$ & 4 & 0.013 & -0.143 \\
\hline \multirow{4}{*}{$\begin{array}{l}\text { Basic Industryand } \\
\text { Chemical }\end{array}$} & $1-3$ & 69 & 0.017 & -0.563 \\
\hline & $4-6$ & 134 & 0.028 & 0.055 \\
\hline & $7-9$ & 40 & 0.042 & 0.044 \\
\hline & $10-12$ & 15 & 0.079 & 0.116 \\
\hline \multirow{4}{*}{$\begin{array}{l}\text { Infra struc ture, Utilities } \\
\text { and Transportation }\end{array}$} & $1-2$ & 17 & 0.068 & 0.146 \\
\hline & $3-4$ & 89 & -0.006 & 0.046 \\
\hline & \begin{tabular}{|l|}
$5-6$ \\
\end{tabular} & 84 & -0.005 & 0.006 \\
\hline & $7-8$ & 14 & 0.047 & 0.108 \\
\hline \multirow{4}{*}{ Misc ellaneous Industry } & $1-3$ & 69 & 0.013 & 0.025 \\
\hline & $4-6$ & 84 & 0.019 & 0.153 \\
\hline & $7-9$ & 24 & 0.046 & 0.147 \\
\hline & $10-12$ & 3 & 0.074 & 0.143 \\
\hline \multirow{4}{*}{$\begin{array}{l}\text { Property, Rea1Estate and } \\
\text { Building Construction }\end{array}$} & $1-3$ & 25 & 0.066 & 0.089 \\
\hline & $4-6$ & 134 & 0.068 & 0.122 \\
\hline & $7-9$ & 49 & 0.065 & 0.145 \\
\hline & $10-12$ & 2 & 0.036 & 0.075 \\
\hline \multirow{4}{*}{$\begin{array}{l}\text { Trade, Services and } \\
\text { Investment }\end{array}$} & $1-3$ & 141 & 0.011 & -0.126 \\
\hline & $4-6$ & 242 & 0.039 & 0.065 \\
\hline & $7-9$ & 63 & 0.002 & 0.149 \\
\hline & $10-12$ & 4 & $\begin{array}{l}-0.046 \\
\end{array}$ & -0.186 \\
\hline
\end{tabular}

\section{Lampiran 2}

Masa Jabatan Presiden Direktur terhadap ROA dan ROE

\begin{tabular}{|c|c|c|c|}
\hline Sector & CEOtenure (tahum) & Avg ROA & Avg ROE \\
\hline \multirow{6}{*}{ Agriculture } & $0-3$ & -0.017 & -0.105 \\
\hline & $4-6$ & 0.049 & 0.059 \\
\hline & $7-9$ & 0.039 & 0.054 \\
\hline & $10-12$ & 0.021 & 0.069 \\
\hline & $13-15$ & 0.000 & 0.000 \\
\hline & $>15$ & 0.009 & 0.019 \\
\hline \multirow{6}{*}{$\begin{array}{l}\text { Consumer } \\
\text { Goods } \\
\text { Industry }\end{array}$} & $0-3$ & 0.118 & 0.321 \\
\hline & $4-6$ & 0.145 & 0.273 \\
\hline & $7-9$ & 0.109 & 0.212 \\
\hline & $10-12$ & 0.069 & 0.146 \\
\hline & $13-15$ & 0.024 & 0.049 \\
\hline & $>15$ & 0.051 & 0.077 \\
\hline \multirow{6}{*}{ Mining } & $0-3$ & 0.049 & 0.083 \\
\hline & $4-6$ & 0.000 & 0.243 \\
\hline & $7-9$ & 0.016 & -0.171 \\
\hline & $10-12$ & -0.019 & -3.136 \\
\hline & $13-15$ & -0.140 & 0.520 \\
\hline & $>15$ & 0.080 & 0.113 \\
\hline \multirow{6}{*}{$\begin{array}{l}\text { Basic Industry } \\
\text { and Chemical }\end{array}$} & $0-3$ & 0.020 & 0.036 \\
\hline & $4-6$ & 0.062 & 0.099 \\
\hline & $7-9$ & 0.021 & 0.008 \\
\hline & $10-12$ & 0.014 & 0.021 \\
\hline & $13-15$ & 0.037 & 0.046 \\
\hline & $>15$ & 0.041 & -0.554 \\
\hline \multirow{6}{*}{$\begin{array}{l}\text { Infra struc ture, } \\
\text { Utilities and } \\
\text { Transportation }\end{array}$} & $0-3$ & 0.006 & 0.053 \\
\hline & $4-6$ & -0.004 & 0.026 \\
\hline & $7-9$ & 0.018 & 0.072 \\
\hline & $10-12$ & 0.020 & 0.015 \\
\hline & $13-15$ & -0.009 & -0.028 \\
\hline & $>15$ & -0.014 & -0.024 \\
\hline \multirow{6}{*}{$\begin{array}{l}\text { Miscellane ous } \\
\text { Industry }\end{array}$} & $0-3$ & 0.020 & 0.158 \\
\hline & $4-6$ & 0.020 & 0.030 \\
\hline & $7-9$ & 0.029 & 0.070 \\
\hline & $10-12$ & -0.024 & 0.073 \\
\hline & $13-15$ & -0.036 & -0.008 \\
\hline & $>15$ & 0.035 & 0.100 \\
\hline \multirow{6}{*}{$\begin{array}{l}\text { Property, Real } \\
\text { Estate and } \\
\text { Building } \\
\text { Construction }\end{array}$} & 0.3 & 0.068 & 0.115 \\
\hline & $4-6$ & 0.052 & 0.098 \\
\hline & $7-9$ & 0.074 & 0.347 \\
\hline & $10-12$ & 0.112 & 0.200 \\
\hline & $13-15$ & 0.086 & 0.165 \\
\hline & $>15$ & 0.057 & 0.103 \\
\hline \multirow{6}{*}{$\begin{array}{l}\text { Trade, } \\
\text { Services and } \\
\text { Investment }\end{array}$} & $0-3$ & 0.012 & 0.004 \\
\hline & $4-6$ & 0.025 & 0.025 \\
\hline & $7-9$ & 0.042 & 0.101 \\
\hline & $10-12$ & 0.024 & -0.131 \\
\hline & $13-15$ & 0.029 & 0.032 \\
\hline & $>15$ & 0.056 & 0.085 \\
\hline
\end{tabular}




\section{Lampiran 3}

Persentase Optimal Jumlah Direksi dengan Kewarganegaraan Asing terhadap ROA dan ROE

\begin{tabular}{|c|c|c|c|c|}
\hline Sector & Foreign & Avg ROA & Avg ROE & $\begin{array}{c}\text { Percentage } \\
\text { PMA }\end{array}$ \\
\hline \multirow{3}{*}{ Agriculture } & $0 \%-14,3 \%$ & 0.031 & 0.045 & \multirow{3}{*}{$20.00 \%$} \\
\hline & $14,4 \%-28,6$ & 0.011 & 0.017 & \\
\hline & $28,7 \%-42,9$ & -0.069 & -0.439 & \\
\hline \multirow{3}{*}{$\begin{array}{l}\text { Consumer } \\
\text { Goods Industry }\end{array}$} & $0 \%-25 \%$ & 0.054 & 0.019 & \multirow{3}{*}{$59.38 \%$} \\
\hline & $26 \%-50 \%$ & 0.264 & 0.594 & \\
\hline & $51 \%-75 \%$ & 0.214 & 1.036 & \\
\hline \multirow{3}{*}{ Mining } & $0 \%-25 \%$ & 0.025 & 0.079 & \multirow{3}{*}{$40.00 \%$} \\
\hline & $26 \%-50 \%$ & 0.016 & -0.307 & \\
\hline & $51 \%-75 \%$ & 0.097 & 0.223 & \\
\hline \multirow{3}{*}{$\begin{array}{l}\text { Basic Industry } \\
\text { and Chemical }\end{array}$} & $0 \%-25 \%$ & 0.023 & -0.186 & \multirow{3}{*}{$48.84 \%$} \\
\hline & $26 \%-50 \%$ & 0.076 & 0.116 & \\
\hline & $51 \%-75 \%$ & 0.022 & 0.049 & \\
\hline \multirow{3}{*}{\begin{tabular}{|l} 
Infra structure, \\
Utilities and \\
Transportation \\
\end{tabular}} & $0 \%-25 \%$ & 0.012 & 0.064 & \multirow{3}{*}{$47.06 \%$} \\
\hline & $26 \%-50 \%$ & -0.019 & -0.033 & \\
\hline & $51 \%-75 \%$ & -0.033 & -0.042 & \\
\hline \multirow{4}{*}{$\begin{array}{l}\text { Miscellaneous } \\
\text { Industry }\end{array}$} & $0 \%-25 \%$ & 0.022 & 0.113 & \multirow{4}{*}{$43.33 \%$} \\
\hline & $26 \%-50 \%$ & 0.038 & 0.065 & \\
\hline & $51 \%-75 \%$ & 0.000 & 0.046 & \\
\hline & $75 \%-100 \%$ & 0.031 & 0.115 & \\
\hline \multirow{3}{*}{\begin{tabular}{|l} 
Property, Real \\
Estate and \\
Building \\
Construction \\
\end{tabular}} & $0 \%-25 \%$ & 0.065 & 0.121 & \multirow{3}{*}{$34.29 \%$} \\
\hline & $26 \%-50 \%$ & 0.090 & 0.144 & \\
\hline & $51 \%-75 \%$ & 0.081 & 0.109 & \\
\hline \multirow{3}{*}{\begin{tabular}{|l} 
Trade, \\
Services and \\
Investment \\
\end{tabular}} & $0 \%-25 \%$ & 0.020 & 0.023 & \multirow{3}{*}{$50.67 \%$} \\
\hline & $26 \%-50 \%$ & -0.005 & -0.220 & \\
\hline & $51 \%-75 \%$ & 0.167 & 0.230 & \\
\hline
\end{tabular}

\section{Lampiran 4}

Persentase Jabatan Direksi Asing

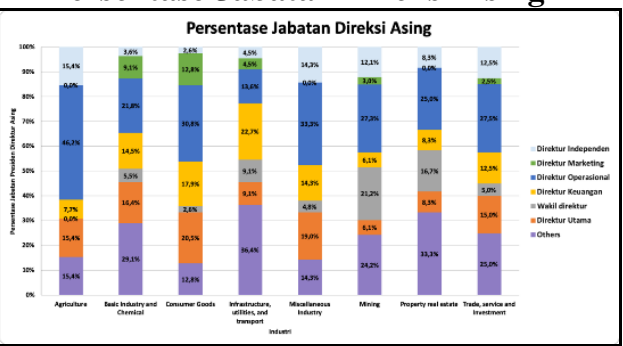

